\title{
Bottom-up and top-down control of small pelagic forage fish: factors affecting age-0 herring in the Strait of Georgia, British Columbia
}

\author{
Jennifer L. Boldt ${ }^{1, *}$, Matthew Thompson ${ }^{1}$, Christopher N. Rooper ${ }^{2}$, Douglas E. Hay ${ }^{3}$, \\ Jacob F. Schweigert ${ }^{3}$, Terrance J. Quinn $\mathrm{II}^{4}{ }$, Jaclyn S. Cleary ${ }^{1}$, Chrys M. Neville ${ }^{1}$ \\ ${ }^{1}$ Fisheries and Oceans Canada (DFO), Nanaimo, BC V9T 6N7, Canada \\ ${ }^{2}$ National Marine Fisheries Service, Alaska Fisheries Science Center, Seattle, WA 98115, USA \\ ${ }^{3}$ Emeritus, Fisheries and Oceans Canada, Nanaimo, BC V9T 6N7, Canada \\ ${ }^{4}$ Juneau Center, School of Fisheries and Ocean Sciences, University of Alaska Fairbanks, AK 99801, USA
}

\begin{abstract}
Small pelagic fish are key planktivores and prey in marine ecosystems, and their population abundances undergo strong temporal and spatial variability. Top-down (predator controlled) and bottom-up (prey-driven) processes during early life history are important for determining forage fish survival and recruitment. We examined biological and environmental factors hypothesized to influence age-0 Pacific herring Clupea pallasi in the Strait of Georgia (SOG), British Columbia, Canada. Primarily bottom-up processes affected interannual variability in age-0 herring abundance and condition, with some evidence of top-down effects on condition. Age-0 herring abundance increased with increasing adult spawning biomass and peaked when most adults spawned about $20 \mathrm{~d}$ prior to the peak spring primary production bloom. This timeline would temporally align first-feeding herring larvae with their prey, such as small copepods. Age-0 herring abundance also increased with increasing juvenile salmon abundance, indicating that conditions favourable for herring were also favourable for their predators and competitors. Age-0 herring condition decreased with increasing spawning biomass, increased when most adults spawned closer to the peak spring bloom, increased with increasing temperatures above $8.2^{\circ} \mathrm{C}$, and increased then stabilized with increasing prey zooplankton density. Age-0 herring condition had a dome-shaped relationship with predator abundance, indicating that high predator abundances negatively affected fish condition. Study results suggest that density-dependent processes, such as intraspecific competition, may be important in the SOG. A positive correlation between age-0 herring abundance and subsequent age-3 recruit abundance may provide a leading indicator of low recruitment years.
\end{abstract}

KEY WORDS: Age-0 herring · Abundance · Condition · Bottom-up · Top-down · Forage fish · Strait of Georgia $\cdot$ Density dependence

\section{INTRODUCTION}

Processes occurring during the early life history of fish have been hypothesized as being important for determining fish survival and recruitment (Cushing 1969, Lasker 1975, Parrish et al. 1981, Schweigert et al. 2013). Small pelagic forage fish have been studied

${ }^{*}$ Corresponding author: jennifer.boldt@dfo-mpo.gc.ca

${ }^{\S}$ Advance View was available online April 17, 2018 extensively, and numerous hypotheses have been proposed to explain recruitment variability (Hjort 1914, Cushing 1972, Sinclair \& Iles 1989, Bakun 1993), each with varying amounts of evidentiary support (Leggett \& Deblois 1994). For example, bottomup (prey-driven) mechanisms are important in Hjort's (1914) critical period hypothesis, which states that

(C) Fisheries and Oceans Canada, Terrance J. Quinn, and outside the USA, The US Government 2019. Open Access under Creative Commons by Attribution Licence. Use, distribution and reproduction are unrestricted. Authors and original publication must be credited. 
the oceanographic environment affects larval survival, thereby affecting recruitment success. In Lasker's (1975) 'stability' hypothesis, a stable environment is needed to allow successful feeding by larvae. There are additional bottom-up hypotheses that link larval survival and recruitment to ocean transport (Parrish et al. 1981), mesoscale oceanographic events (Sinclair \& Iles 1989), and enrichment, retention, and concentration (Bakun 1993). Cushing's (1969) match-mismatch hypothesis states that the temporal overlap of fish larvae and their prey determines year class strength. Fish that acquire enough energy stores and are in good condition can also survive periods of low food availability such as their first winter (Paul et al. 1998, Foy \& Paul 1999, Frisk et al. 2015). Top-down (predator-driven) processes have been identified as important in other hypotheses. For example, fast growth in good feeding conditions has been hypothesized to shorten the duration of exposure to predators (Cushing \& Harris 1973, Bailey \& Houde 1989, Meekan \& Fortier 1996). Forage fish in 'wasp-waist' ecosystems can be driven by both topdown and bottom-up processes (Cury et al. 2000). The importance of top-down and bottom-up processes on fish growth and recruitment varies among species, regions, and life history stage, but are likely of particular importance during the pre-juvenile phase (Houde 1987, Leggett \& Deblois 1994).

Several studies have examined environmental and biological drivers of Pacific herring Clupea pallasi recruitment (e.g. Stocker et al. 1985, Schweigert et al. 2013). For example, environmental variables, along with adult herring spawning biomass, have been identified as drivers of herring recruitment, including sea surface temperature, salinity, sea level, river discharge, and Ekman transport (Stocker et al. 1985, Stocker \& Noakes 1988, Schweigert \& Noakes 1990, Zebdi \& Collie 1995). Multiple environmental variables that are region- or stock-specific improve forecasts of Pacific herring recruitment (Williams \& Quinn 2000, Dreyfus-León \& Chen 2007, DreyfusLeón \& Schweigert 2008). The effect of temperature and salinity on fish survival between the egg and first-feeding larval stages is a potential mechanism affecting recruitment (Alderdice \& Hourston 1985). Reum et al. (2013) found that the size of age-0 Pacific herring in Puget Sound was related to temperature in the summer and to abundance in the fall-the latter suggesting density dependence. Pacific herring off the west coast of Vancouver Island (WCVI) may be driven by several processes, such as prey availability, competition, and predation (Schweigert et al. 2010). The abundance of Strait of Georgia (SOG) age-0
Pacific herring in the fall has been previously attributed to the match or mismatch (i.e. Cushing's 1969 match-mismatch hypothesis) in the timing between larval herring energy requirements and the spring plankton bloom (Schweigert et al. 2013).

Pacific herring in the SOG, which are an important species for First Nations and commercial fishers, undergo considerable variability in recruitment abundances due in large part to mortality during their first months of life (Schweigert et al. 2009). In late winter and spring, adult SOG herring (age-3 and older) migrate from summer feeding areas in coastal shelf waters off the WCVI to the SOG to spawn (Taylor 1964). Eggs are predominately deposited on shallow macrophytes, such as eelgrass, rockweed, kelps, and algae (Humphreys \& Hourston 1978, Haegele et al. 1981). Herring egg hatching time is temperature dependent and can range from 9 to 33 d (Outram 1955, Alderdice \& Velsen 1971, Taylor 1971, Alderdice \& Hourston 1985). Larval yolk reserves are utilized in approximately 1 or $2 \mathrm{wk}$, depending on temperatures and salinities (Alderdice \& Velsen 1971). After hatching and yolk absorption, age-0 herring spend their first summer in nearshore areas, close to the sea floor during daytime hours and dispersed in the upper portion of the water column during nighttime hours (Haegele \& Armstrong 1997, Emmett et al. 2004).

Primary predators of age-0 herring in the SOG include juvenile coho salmon Oncorhynchus kisutch and Chinook salmon O. tshawytscha that consume age-0 herring during the summer and fall (Beamish et al. 2004, Duffy et al. 2010, Preikshot et al. 2013, Kemp 2014). Other age-0 herring predators might include adult Chinook and coho salmon, Pacific hake Merluccius productus, spiny dogfish Squalus suckleyi, seabirds, and perhaps pinnipeds (Schweigert et al. 2010); however, in the SOG, there is either limited information on the specific age of herring that these predators consume and/or there is limited time series of the abundance of these predators. Potential competitors include juvenile chum $O$. keta, pink salmon O. gorbuscha, and sockeye salmon O. nerka, which all share common prey items (such as amphipods, copepods, and euphausiids) with age-0 herring (Haegele 1997, Beamish et al. 2004).

The objective of this study was to examine the influence of biological and environmental factors on the interannual variability of SOG age-0 herring abundance and condition. Factors included adult herring spawning biomass and timing of spawning, prey availability, predator abundance, competitor abundance, and ocean temperatures. It was pre- 
dicted that age-0 herring abundance would be higher with fewer predators (Chinook, coho), fewer competitors (pink, chum, sockeye), more prey (zooplankton), higher adult herring spawning biomass, and if the date of peak adult herring spawning biomass temporally aligned hatched larvae with their prey. The same predictions applied for age-0 herring condition, except it was expected that condition would be higher when there were more predators (Chinook and coho) that would selectively remove fish in poorer condition (Tucker et al. 2016), fewer adult herring spawning (resulting in less intraspecific competition), and with warmer temperatures (resulting in higher productivity and food availability).

\section{MATERIALS AND METHODS}

\subsection{Field and laboratory sampling}

The SOG age-0 Pacific herring Clupea pallasi survey time series was used to estimate the relative abundance and condition of age-0 herring after their first summer, following methods described in Boldt et al. (2015). The survey was conducted annually during September and October from 1992 to 2016 (except 1995) using survey methodology and transect locations described in Thompson et al. (2003). There were 10 core transects, each with 3 to 5 core stations, distributed at approximately equal intervals around the perimeter of the SOG (Fig. 1, Table 1). Sampling was conducted after dusk when herring were near the surface, and generally one transect was sampled per night over the course of a 4 to $7 \mathrm{~h}$ period. A purse seine was used for all fishing events, and techniques (e.g. pursing speed and drumming of net) were kept as uniform as possible among years. During 1996 to 2016, the net used was $183 \mathrm{~m}$ long $\times 27 \mathrm{~m}$ deep, resulting in an area fished of $2660 \mathrm{~m}^{2}$ (based on the geometric formula for the area of a circle). Prior to 1995, the net length was $220 \mathrm{~m}$ long $\times 27 \mathrm{~m}$ deep, resulting in an area fished of $3852 \mathrm{~m}^{2}$. Net mesh sizes remained the same throughout the time series. The 11.6 m Fisheries Research Vessel 'Keta' was used from 1992 to 1994 and the $12 \mathrm{~m}$ Fisheries Research Vessel 'Walker Rock' was used from 1996 to 2016.

Some exceptions in sampling occurred; for example, from 1997 to 1999, only 2 or 3 stations were sampled along core transects. In some cases the presence of large abundances of jellyfish inhibited the ability to acquire representative fish samples, and in some cases inclement weather prevented sampling. Over the 24 yr time series, there was a total possible sam-

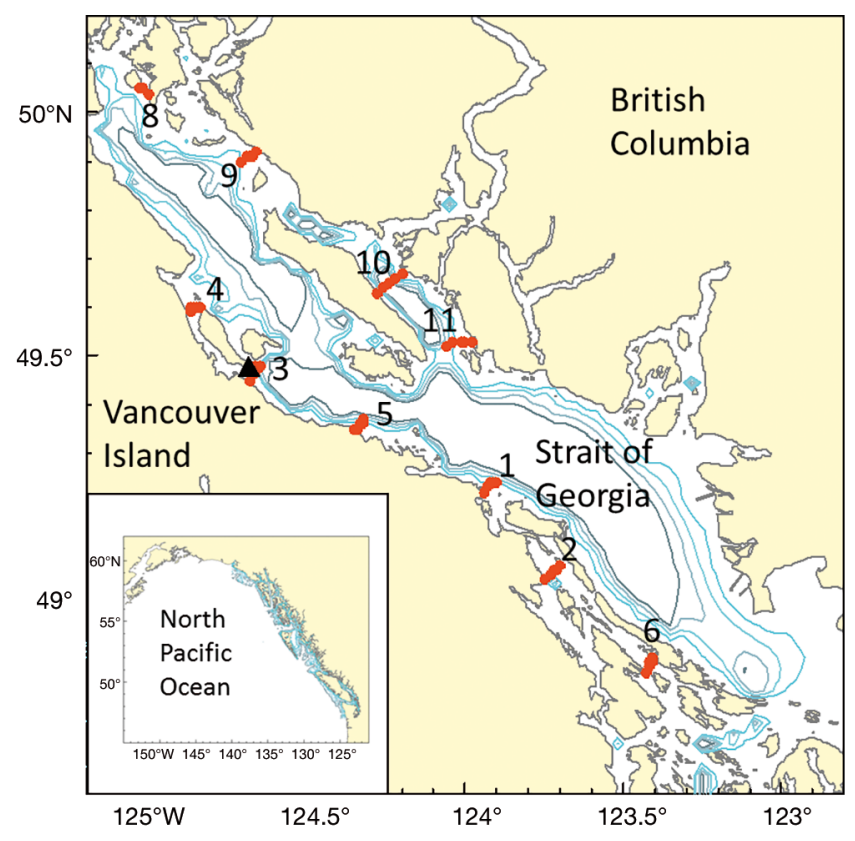

Fig. 1. Purse seine set locations along the 10 core transects (1 to 6 and 8 to 11; there is no transect 7 ) of the Strait of Georgia juvenile Pacific herring survey. Grey and turquoise lines represent the 50,100,150, and $200 \mathrm{~m}$ isobaths. $\Delta$ : Chrome Island lighthouse

ple size of 1152 stations from the 10 core transects and 48 core stations. The realized sample size was 1056 stations because 96 stations were not sampled (Boldt et al. 2015, Thompson \& Boldt in press, Thompson et al. in press).

For most purse seine sets, it was possible to land the entire catch for biological sampling. On occasion, it was not practical to land a large set in its entirety, so subsampling was necessary and total catch weight was visually estimated (see Boldt et al. 2015). Catch per unit effort (CPUE) was calculated as catch weight (g) divided by the area fished by the net. All fish (or a subsample of fish) were retained for sampling in the laboratory, with the exception of large predator species (e.g. adult salmon and flatfish), which were individually measured in the field. During 1992 to 2013, all fish were preserved in a $10 \%$ formalin and seawater solution, whereas from 2014 to 2016, fish were frozen. In the laboratory, herring from each station were measured to standard length $(\mathrm{mm})$ and weighed (g). Herring were assigned to age-class by examining the length frequencies (e.g. Thompson et al. 2013). No corrections to fish lengths or weights were made to account for shrinkage due to preservation methods used (formalin from 1992 to 2013 vs. freezing from 2014 to 2016), because the difference in percent shrinkage between the 2 preservation methods has 
Table 1. Core station and transect names and locations sampled as part of the Strait of Georgia age-0 Pacific herring survey during September and October 1992 to 2016 (no survey in 1995; there is no Transect 7)

\begin{tabular}{|c|c|c|c|c|}
\hline $\begin{array}{l}\text { Tran- } \\
\text { sect }\end{array}$ & Transect name & Stn & $\begin{array}{c}\text { Latitude } \\
\left({ }^{\circ} \mathrm{N}\right)\end{array}$ & $\begin{array}{l}\text { Longitude } \\
\left({ }^{\circ} \mathrm{W}\right)\end{array}$ \\
\hline 1 & Clarke Rock & 1 & 49.22 & 123.94 \\
\hline 1 & Clarke Rock & 2 & 49.23 & 123.93 \\
\hline 1 & Clarke Rock & 3 & 49.24 & 123.92 \\
\hline 1 & Clarke Rock & 4 & 49.24 & 123.91 \\
\hline 1 & Clarke Rock & 5 & 49.24 & 123.90 \\
\hline 2 & Yellow Point & 1 & 49.04 & 123.75 \\
\hline 2 & Yellow Point & 2 & 49.05 & 123.73 \\
\hline 2 & Yellow Point & 3 & 49.06 & 123.72 \\
\hline 2 & Yellow Point & 4 & 49.06 & 123.71 \\
\hline 2 & Yellow Point & 5 & 49.07 & 123.70 \\
\hline 3 & Bowser & 1 & 49.45 & 124.68 \\
\hline 3 & Bowser & 2 & 49.46 & 124.67 \\
\hline 3 & Bowser & 3 & 49.47 & 124.66 \\
\hline 3 & Bowser & 4 & 49.48 & 124.66 \\
\hline 3 & Bowser & 5 & 49.48 & 124.65 \\
\hline 4 & Henry Bay & 1 & 49.59 & 124.87 \\
\hline 4 & Henry Bay & 2 & 49.60 & 124.87 \\
\hline 4 & Henry Bay & 3 & 49.60 & 124.86 \\
\hline 4 & Henry Bay & 4 & 49.60 & 124.85 \\
\hline 4 & Henry Bay & 5 & 49.60 & 124.84 \\
\hline 5 & French Creek & 1 & 49.35 & 124.35 \\
\hline 5 & French Creek & 2 & 49.35 & 124.34 \\
\hline 5 & French Creek & 3 & 49.36 & 124.33 \\
\hline 5 & French Creek & 4 & 49.36 & 124.32 \\
\hline 5 & French Creek & 5 & 49.37 & 124.32 \\
\hline 6 & Trincomali Channel & 1 & 48.85 & 123.43 \\
\hline 6 & Trincomali Channel & 2 & 48.86 & 123.42 \\
\hline 6 & Trincomali Channel & 3 & 48.87 & 123.42 \\
\hline 6 & Trincomali Channel & 4 & 48.87 & 123.41 \\
\hline 6 & Trincomali Channel & 5 & 48.88 & 123.41 \\
\hline 8 & Smelt Bay & 1 & 50.04 & 125.00 \\
\hline 8 & Smelt Bay & 2 & 50.05 & 125.02 \\
\hline 8 & Smelt Bay & 3 & 50.05 & 125.03 \\
\hline 9 & Atrevida Reef & 1 & 49.92 & 124.66 \\
\hline 9 & Atrevida Reef & 2 & 49.91 & 124.67 \\
\hline 9 & Atrevida Reef & 3 & 49.91 & 124.68 \\
\hline 9 & Atrevida Reef & 4 & 49.91 & 124.69 \\
\hline 9 & Atrevida Reef & 5 & 49.90 & 124.71 \\
\hline 10 & Cape Cockburn & 1 & 49.67 & 124.20 \\
\hline 10 & Cape Cockburn & 2 & 49.66 & 124.22 \\
\hline 10 & Cape Cockburn & 3 & 49.65 & 124.24 \\
\hline 10 & Cape Cockburn & 4 & 49.64 & 124.26 \\
\hline 10 & Cape Cockburn & 5 & 49.63 & 124.28 \\
\hline 11 & Secret Cove & 1 & 49.53 & 123.98 \\
\hline 11 & Secret Cove & 2 & 49.53 & 124.00 \\
\hline 11 & Secret Cove & 3 & 49.53 & 124.01 \\
\hline 11 & Secret Cove & 4 & 49.53 & 124.04 \\
\hline 11 & Secret Cove & 5 & 49.52 & 124.06 \\
\hline
\end{tabular}

been shown to be small. If conversion formulae for Gadus chalcogramma of similar sizes (Buchheister \& Wilson 2005) were used, preserving an average sized age-0 herring $(87.6 \mathrm{~mm}$ and $8.6 \mathrm{~g})$ would result in a difference of $1.4 \mathrm{~mm}(1.6 \%)$ in length and $0.3 \mathrm{~g}$ $(3.7 \%)$ in weight between freezing fish and preserving fish in $10 \%$ formalin.

\subsection{Relative abundance of age-0 herring}

To calculate an index of the relative abundance of age-0 herring, 2-stage sampling formulae (Thompson 1992) were used to calculate the mean and variance of weight CPUE (see Boldt et al. 2015 for detailed methods). The first stage of sampling was transects, assumed to be selected quasi-randomly without replacement. The second stage was stations that were systematically selected without replacement so that they were evenly spaced along transects. In 2-stage sampling, mean weight CPUE and variance were calculated using the second stage (stations) for each transect. Next, the mean weight CPUE and variance were calculated across the first stage averages (transects) to compute an overall mean. The variances resulting from each of the 2-stages of sampling were then combined to calculate an overall variance estimate (Thompson 1992). We assumed for our analyses, as stated in Szarzi et al. (1995, p. 279): '(1) sample sizes at each stage were assumed to be small compared to the total number of possible samples, therefore finite population correction factors were ignored; (2) to simplify calculations of means and variances it was assumed that the total numbers of possible samples at each stage were equal; and (3) it was assumed that the systematic random sampling at the second stage could be treated as simple random sampling for the calculation of variances.' Analyses were performed using R version 3.1.0 (R Core Team 2014).

\subsection{Size and condition}

Mean annual age-0 herring lengths and weights were calculated by averaging all measurements in each year. Individual herring weights were log transformed and regressed against log-transformed standard lengths for all years combined. Mean residuals from the log-transformed length-weight regression were calculated as an index of fish condition (hereafter referred to as length-weight residuals or condition); positive residuals indicate that fish were heavier for a given length than average and, hence, in better condition. An analysis of variance (ANOVA) was used to determine if the mean values of fish condition varied among years and a $k$-sample Anderson-Darling test was used to test if the distributions of condition values were similar among years. The R package 'kSamples' was used for this test (R Core Team 2014, Scholz \& Zhu 2016). 


\subsection{Zooplankton}

Zooplankton samples were collected using stepped oblique tows at 2 to 5 stations on each transect immediately prior to and at the same locations where herring were sampled (Haegele 1997, Thompson et al. 2003). The net was a dual $19 \mathrm{~cm}$ diameter bongo net with $350 \mu \mathrm{m}$ mesh, equipped with a flowmeter to acquire the volume filtered. Samples were collected from 20 or $10 \mathrm{~m}$ (for shallow stations) depths using

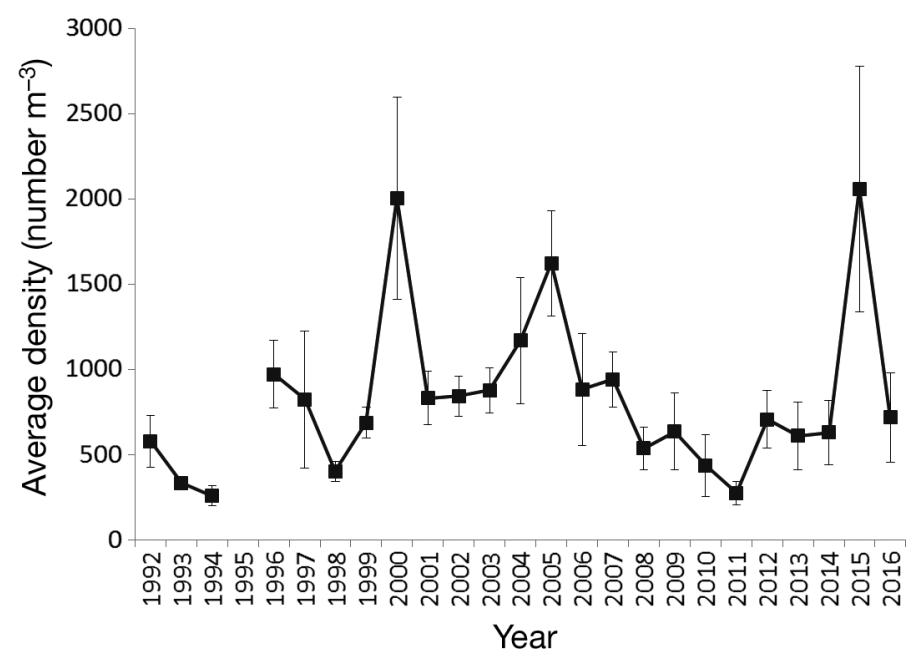

Fig. 2. Average $( \pm \mathrm{SE})$ density of zooplankton animals that are prey for age-0 Pacific herring in the Strait of Georgia, September and October 1992 to 2016

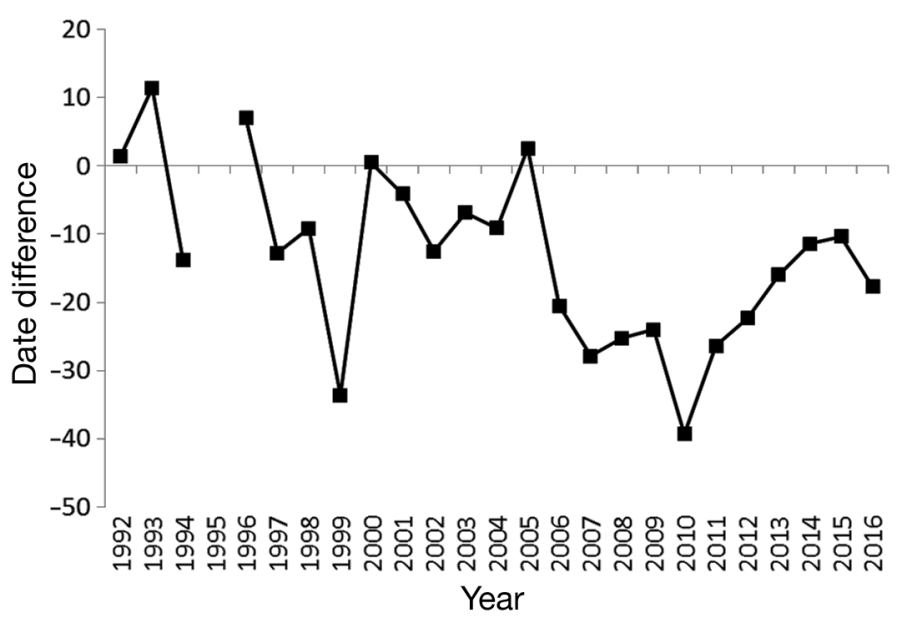

Fig. 3. Date difference (days) between when most adult Pacific herring spawned relative to the date of the peak spring primary production bloom during 1992 to 2016 (except 1995). Date difference is the mid-spawn date, weighted by spawn biomass, minus spring bloom date (peak spring bloom date from Allen \& Wolfe 2013 and Allen et al. 2017). Values $>0$ indicate that most adult herring spawned after the peak spring bloom date; values $<0$ indicate that most adult herring spawned before the peak spring bloom date methods outlined in Haegele (1997) and preserved in $10 \%$ formalin. In the lab, zooplankton species were enumerated to the lowest possible taxonomic group and densities calculated.

The density of age-0 herring prey in zooplankton samples was used as an indicator of prey availability. Previously published studies show that the main prey groups (percent number) of age-0 herring include copepods (58\%; such as Metridia pacifica), barnacle cyprids and nauplii $(10 \%)$, larvaceans $(7 \%), E u-$ phausia pacifica adults and larvae $(2 \%)$, amphipods $(2 \%)$, crab megalops and zoeae $(2 \%)$, and other invertebrates $(17 \%$; e.g. cladocerans, ostracods, insects, chaetognaths, isopods, others; Haegele 1997, Haegele et al. 2005). To determine the availability of age- 0 herring prey in the water column, densities of these prey groups (number $\mathrm{m}^{-3}$ ) in each zooplankton sample were summed for each station and then averaged over all stations in each year (Fig. 2).

\subsection{Models}

To test whether top-down or bottom-up factors affect age-0 herring, general additive models (GAMs) were used to explore the relationships between age-0 herring abundance and condition, as response variables, and biotic and abiotic predictor variables. The first predictor variable was an index of adult herring spawning biomass that would have spawned the age- 0 progeny. The index was calculated from a dive survey of egg deposition conducted annually in the SOG that provided an index of eggs, from which adult spawning biomass was back calculated (see Schweigert 1993 for methods). In addition, the dates and adult spawning biomass were recorded for individual spawning events, so the date when most herring spawning occurred was known. The second predictor variable was the difference between the mean date of spawning (weighted by spawning biomass) and the spring bloom date. Negative values indicated that most herring spawned prior to the spring bloom and positive values indicated that most herring spawned after the spring bloom (Fig. 3). Model-based estimates of the peak spring bloom timing were provided by Allen et al. (2017), as calculated in Allen \& Wolfe (2013). Shortly after the spring bloom date, it would be expected that zooplankton, such as small copepods (Mackas et al. 2013), would be available as prey for larval herring that have exhausted their yolk sac. The spring bloom date is therefore used as an indicator of subsequent zooplankton prey availability to age-0 herring. A third predictor variable in 
the GAMs was the annual estimate of average density of age-0 herring prey in zooplankton samples collected during the age-0 herring survey as an indicator of prey availability. Temperature has been linked to processes at multiple herring life history stages, such as hatch rates, survival, metabolism, recruitment, and maturation (Alderdice \& Hourston 1985, Hay 1985, Winters et al. 1986, Zebdi \& Collie 1995, Toresen \& Ostvedt 2000). A fourth predictor variable was sea surface temperatures (SST), as measured at the Chrome Island lighthouse in the SOG (www.pac.dfompo.gc.ca/science/oceans/data-donnees/lighthousesphares/index-eng.html; accessed 23 September 2016). Monthly averages in December to March were used to estimate the winter SST.

To examine top-down and competitive factors, we included indices of predators and competitors as the final 2 predictor variables. Juvenile Chinook and coho salmon are predators of age-0 herring in the SOG during July to September (Beamish et al. 2004, Duffy et al. 2010, Kemp 2014), whereas juvenile chum, pink, and sockeye salmon are potential competitors because they consume similar prey items as age-0 herring (Beamish et al. 2004). Predators may reduce the abundance of age- 0 herring or they may affect age-0 herring condition. For example, predators may only select prey that are in poor condition relative to those that are available (Tucker et al. 2016); therefore, the fish that survived would be larger and in better condition. SOG surface trawl surveys conducted by Fisheries and Oceans Canada (DFO) in July and September each year provide an index of relative abundance (CPUE; no. of fish caught $\mathrm{h}^{-1}$ ) of each juvenile salmon species (Beamish et al. 2012, C. Neville, DFO unpubl. data). The sum of species-specific average CPUEs provided indices of relative predator (juvenile Chinook and coho salmon) and competitor (juvenile chum, pink, and sockeye salmon) abundances.

Age-0 herring abundance was log transformed to achieve normality (log-transformed weight CPUE) and modeled as a smooth spline function of herring spawning biomass, the difference between midspawn date weighted by herring spawning biomass and the spring bloom date, prey zooplankton density, predator CPUE, and competitor CPUE. Age-0 herring condition (log-transformed length-weight residuals) was modeled as a function of the same factors but also with Chrome Island lighthouse SST (winter average during December to March).

To ensure predictor variables included in the models were not overly correlated, multicollinearity among variables was examined. Variance inflation factors were also examined to check for collinearity among predictor variables using the method of Zuur et al. (2009). All hypothesized variables were included in initial GAMs and knots were constrained to 3 to reduce overfitting. Non-significant variables were removed one at a time, starting with the highest $\mathrm{p}$-value, if 2 of 3 conditions were met (Wood \& Augustin 2002, Weinberg \& Kotwicki 2008): (1) p > 0.05 ; (2) generalized cross validation (GCV) score was reduced when the variable was eliminated; and (3) effective degrees of freedom were close to 1.0. The 'mgcv' (Wood 2004, 2006) library in R was used to run the GAM models.

\section{RESULTS}

\subsection{Age-0 herring abundance, size, and condition}

Of the 1056 seine net samples collected between 1992 and 2016, 836 samples contained age-0 Pacific herring Clupea pallasi; 220 samples had none. Three years had high proportions of samples with no age-0 herring: $1993(0.46 ; 22$ of the 48 samples); 2005 (0.74; 34 of the 46 samples); and $2007(0.87 ; 40$ of the 46 samples). Together, the zero-catches in these 3 years comprised almost half of all zero-catches in the time series.

Estimates of age-0 herring CPUE (catch weight) varied annually, with no overall trend during 1992 to 2016 (Fig. 4). Age-0 herring CPUE peaked every 2 or 3 yr, with peaks occurring in even years from 2004 to 2012. The index was relatively low and stable during 2013 to 2016 compared to the peaks within the time

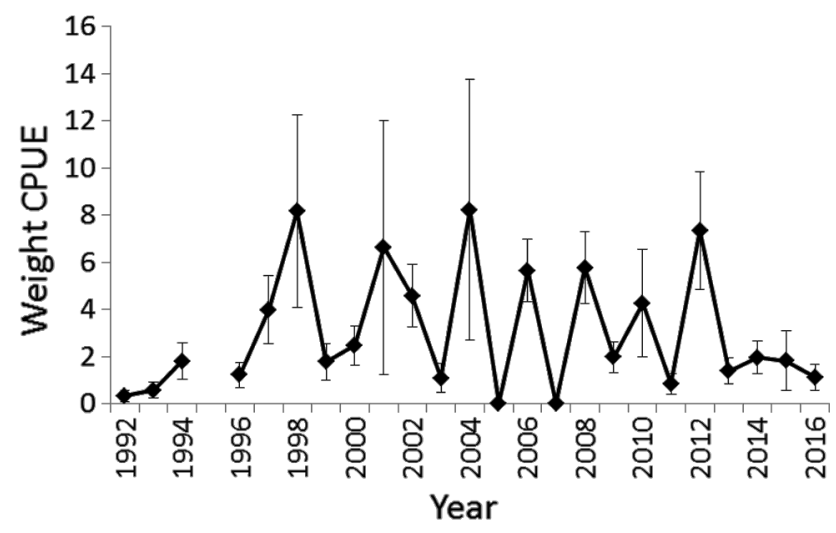

Fig. 4. Estimates of catch weight per unit effort (Weight CPUE; $\mathrm{g} \mathrm{m}^{-2}$ ) of age-0 Pacific herring caught in the Strait of Georgia age-0 herring survey at core transects and stations during September and October 1992 to 2016 (no survey in 1995). Standard error bars (using the Thompson 1992 variance estimator) are shown 
series. High estimates of variability were associated with peak estimates; the survey CV was 0.47 averaged across all years.

Average age-0 herring lengths and weights ranged from 75 to $99 \mathrm{~mm}$ and 5 to $13 \mathrm{~g}$, respectively (Fig. 5). During the time series, there was no significant linear temporal trend in mean lengths or weights of age-0 herring (Fig. 5). There was, however, a temporal shift in length-weight residuals (condition) of age-0 herring that was negative from 1992 to 2004 and 2006, and positive during 2005 and 2007 to 2016 (Fig. 6). The mean condition of age-0 herring differed significantly among years $(\mathrm{p}<0.001)$ and increased during 1997 to about 2011 (Fig. 6). The distributions of condition values differed significantly among years $(\mathrm{p}<$ 0.001 ), with a broader range of values in years prior to 2005 compared to years after 2007.

\subsection{Models}

Variables retained in the final age- 0 herring abundance model were herring spawning biomass, the timing of when most herring spawned relative to the

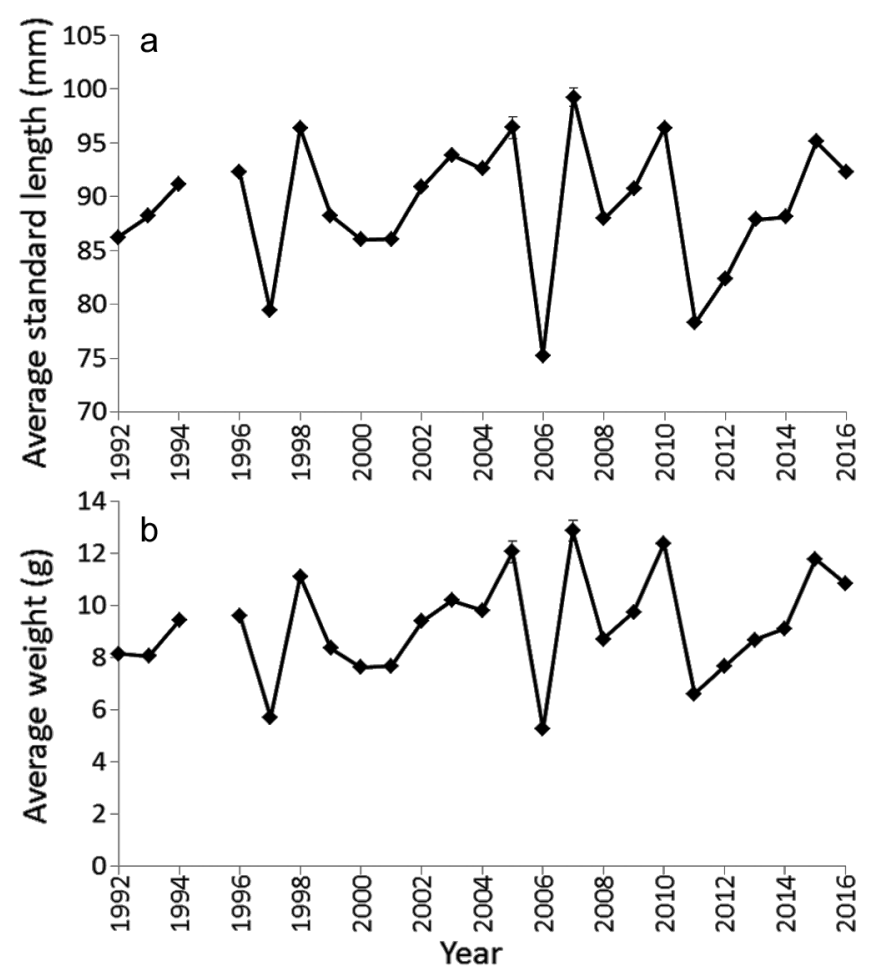

Fig. 5. Age-0 Pacific herring mean (a) standard lengths and (b) weights measured during the fall age-0 herring survey, September and October 1992 to 2016 (no survey in 1995). Standard error bars are shown, but are small: 0.1 to $3.5 \%$ of the mean values

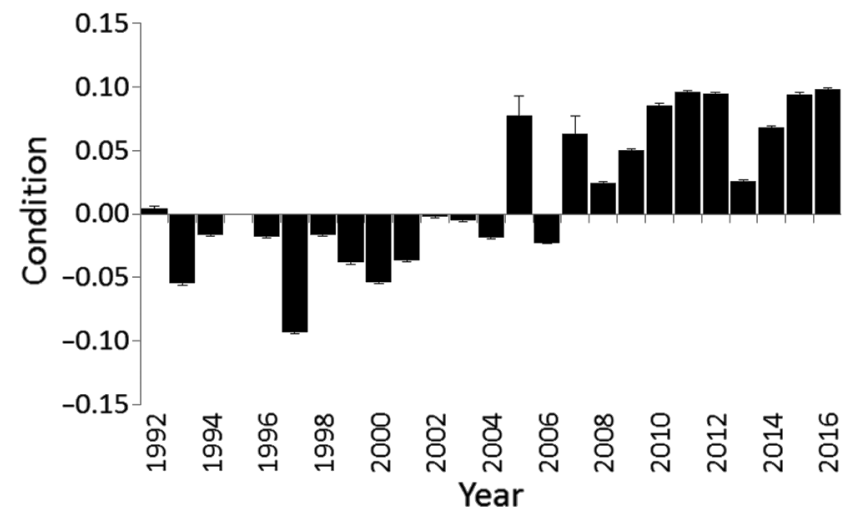

Fig. 6. Age-0 Pacific herring condition (length-weight residuals from a double log-transformed length-weight relationship) in the Strait of Georgia, during September and October 1992 to 2016 (except 1995). Standard error bars are shown

spring bloom, predator abundance, and competitor abundance (Fig. 7). Prey zooplankton density was not included in the final model. Total deviance explained by this model was $54 \%$. Age-0 herring abundance (1) increased with increasing herring spawning biomass, (2) was highest when the peak herring spawn occurred about $20 \mathrm{~d}$ prior to the spring bloom, (3) increased with increasing predator abundance, and (4) increased with increasing competitors and then leveled off (with high variability and few data points; Fig. 7).

In the final age- 0 herring condition GAM, variables retained were herring spawning biomass, the timing of when most herring spawned relative to the spring bloom, predator abundance, SST, and prey zooplankton density (Fig. 8). The variable excluded from the final model was competitor abundance. Total deviance explained by this model was $87 \%$. Age- 0 herring condition (1) decreased with increasing spawning biomass, (2) increased when most herring spawned closer to spring bloom, (3) increased with increasing temperatures above $8.2^{\circ} \mathrm{C}$, (4) followed a dome-shaped relationship with predator abundance, and (5) increased to level with increasing prey zooplankton density (with high variability and few data points at high prey zooplankton densities; Fig. 8).

\section{DISCUSSION}

In this study we identified important drivers of age0 Pacific herring Clupea pallasi abundance and condition. Age-0 herring abundance and condition were linked to the date when most herring spawned relative to spring bloom date. We did not detect any negative impacts of salmon competitors (Oncorhynchus 

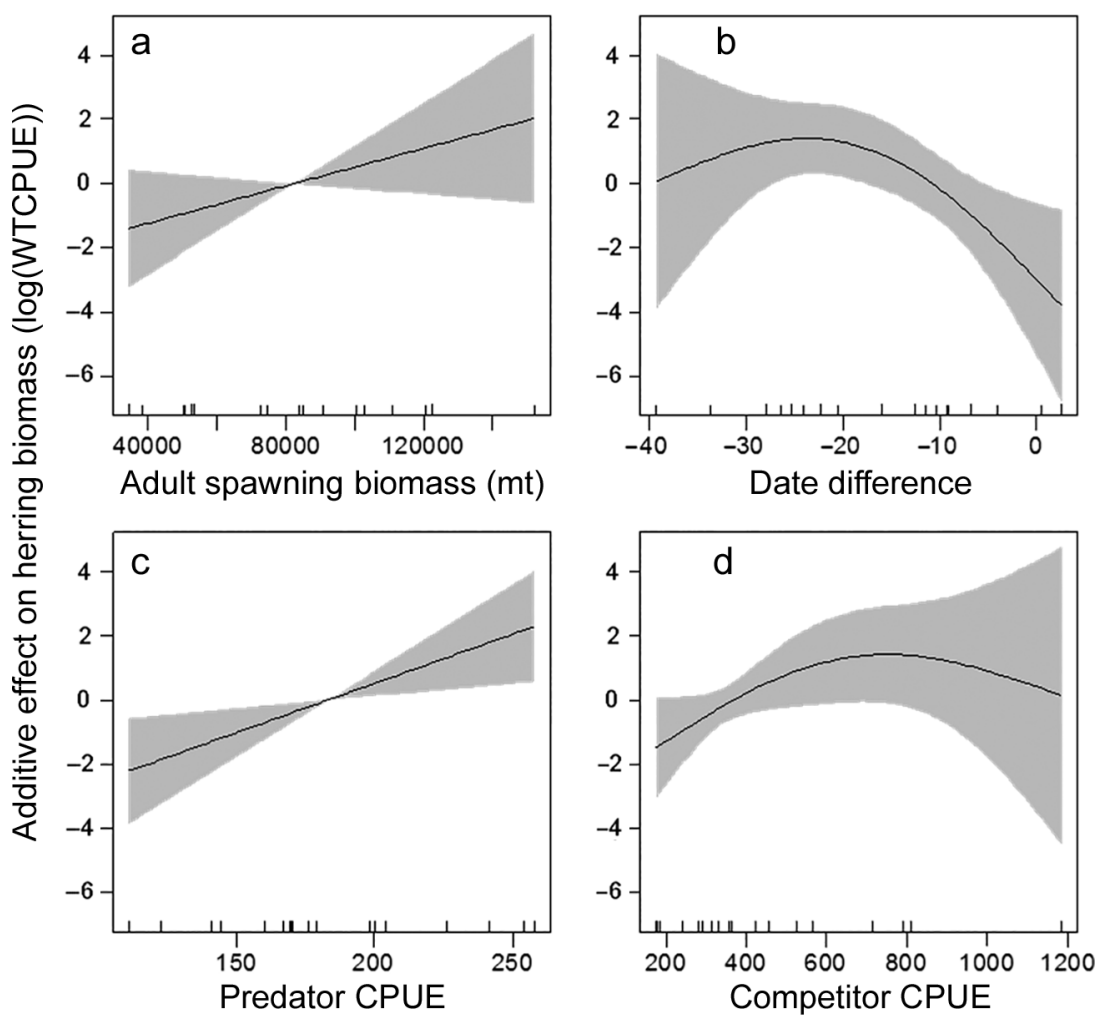

Fig. 7. General additive model results showing the additive effect of predictor variables on the relative index of age- 0 Pacific herring biomass (log catch weight per unit effort [WTCPUE]). Predictor variables that were included in the final model were (a) adult herring spawn biomass, (b) date difference between the date when most adult herring spawned and the peak spring bloom (days), (c) juvenile salmon predator catch per unit effort (CPUE), and (d) juvenile salmon competitor CPUE
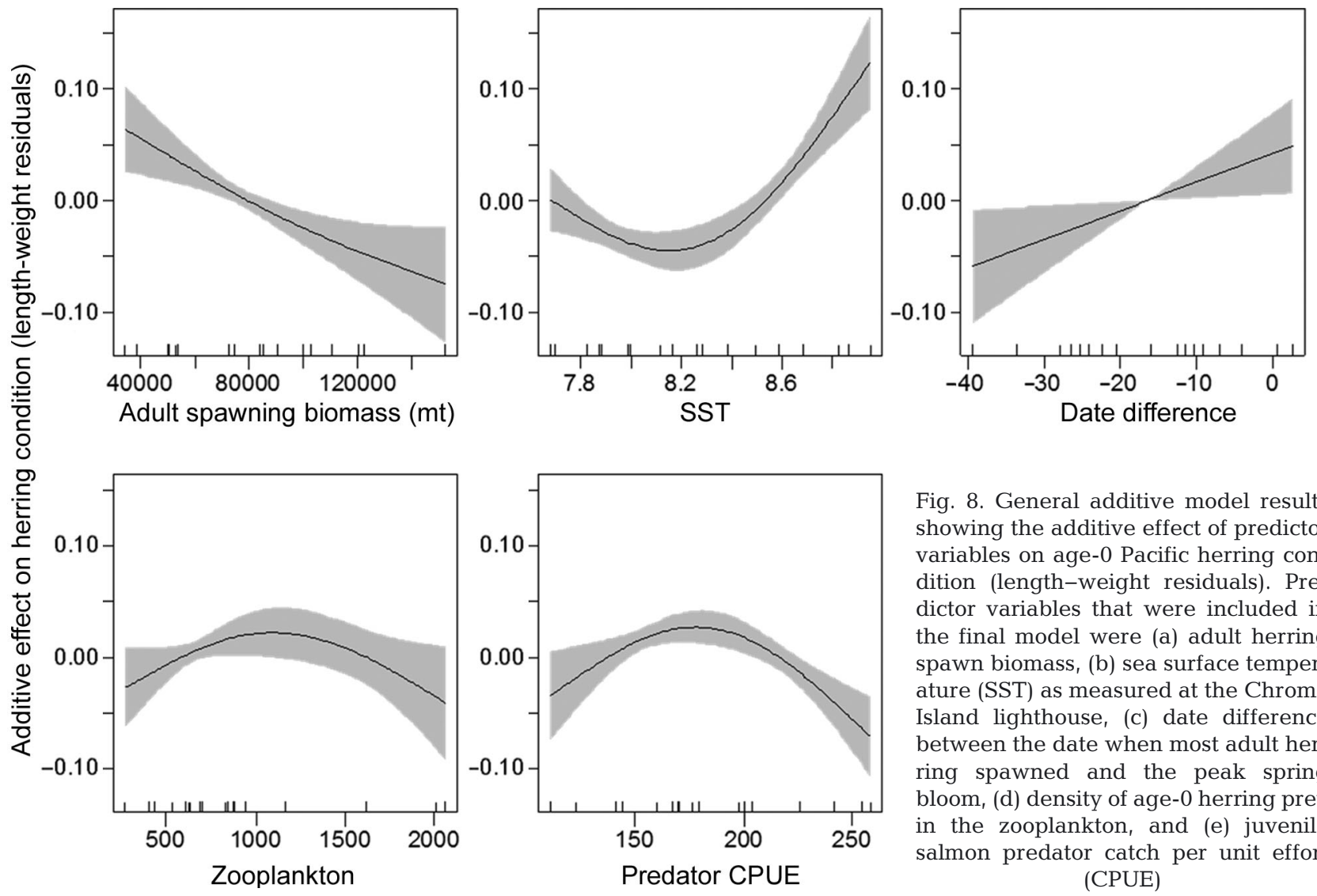

Fig. 8. General additive model results showing the additive effect of predictor variables on age-0 Pacific herring condition (length-weight residuals). Predictor variables that were included in the final model were (a) adult herring spawn biomass, (b) sea surface temperature (SST) as measured at the Chrome Island lighthouse, (c) date difference between the date when most adult herring spawned and the peak spring bloom, (d) density of age-0 herring prey in the zooplankton, and (e) juvenile salmon predator catch per unit effort (CPUE) 
gorbuscha, O. keta, and O. nerka) on herring abundance or condition. Salmon predators $(O$. kisutch and O. tshawytscha) negatively influenced age-0 herring condition (not abundance) at high predator abundances. With this evidence, we conclude that primarily bottom-up processes affect the abundance and condition of SOG age-0 herring, with some evidence of additional top-down effects on herring condition. Previous basin-scale studies also showed that primarily bottom-up processes affected herring (Ware \& Thomson 2005, Perry \& Schweigert 2008), and similar results were evident for adult herring in an adjacent geographic area on the WCVI (Schweigert et al. 2010).

Our herring abundance GAM is consistent with Cushing's (1969) match-mismatch hypothesis and results of Schweigert et al. (2013) because the temporal match or mismatch between prey and first feeding larvae determines, in part, age-0 herring abundance. Schweigert et al. (2013) found that age-0 herring recruitment increased when mean annual spawning occurred 1 to 2 wk prior to the spring bloom. In our study, age-0 herring abundance peaked when more adult herring spawned (i.e. spawning biomass) about $20 \mathrm{~d}$ prior to the peak spring bloom. The intervening period $(20 \mathrm{~d})$ between the peak adult herring spawning and the spring bloom could potentially encompass hatching of herring eggs (Outram 1955, Alderdice \& Velsen 1971, Taylor 1971, Alderdice \& Hourston 1985) and larval yolk-sac absorption (Alderdice \& Velsen 1971). First feeding larvae would, therefore, occur shortly after the peak phytoplankton bloom when zooplankton prey, such as small copepods, became abundant in May (Mackas et al. 2013). Matching first-feeding larval fish with their prey items would improve fish survival to the fall when the age-0 fish were sampled in our survey.

Fish growth, indicated by condition (Smith et al. 1986, Froese 2006), can be affected by changes in the physical and biological environment, such as temperature, salinity, prey abundance, interspecific competition, and/or predation (Flinkman et al. 1998, Casini et al. 2006, Brunel \& Dickey-Collas 2010, Frisk et al. 2015). In this study, model results were contrary to some of our predictions; for example, age-0 herring condition increased when most adult herring spawned closer to the peak spring phytoplankton bloom date (rather than prior to the bloom, as predicted). Perhaps condition is more closely aligned with the peaks in availability of larger zooplankton prey species that would occur after the peak primary production bloom (Mackas et al. 2013), rather than the peak timing of the primary production. As zooplankton prey density increased, so did age-0 herring condition to a point and then leveled off; it is unclear if this was due to the low number of samples at high zooplankton densities or if, at the highest zooplankton abundances, age- 0 herring became prey-saturated and their condition was maximized, or some other factor began to limit age-0 herring condition. Examining zooplankton species composition might provide further insights into factors affecting age-0 herring condition in the SOG. Age-0 herring condition increased with temperatures warmer than $8.2^{\circ} \mathrm{C}$, which was somewhat consistent with our hypothesis that SST is a proxy for prey availability during the first months of feeding.

Results provided no evidence of top-down control or negative effects on herring abundance by juvenile salmon predators or competitors. Counter to predictions, age-0 herring abundance increased as predator and competitor abundance increased; therefore, we conclude that when ocean conditions were favourable for age-0 herring abundance, they were also favourable for juvenile salmon abundance. This supports previous observations in 2007 of common patterns in juvenile herring and juvenile salmon production in the SOG (Beamish et al. 2012). Negative effects of predators were observed for age-0 herring condition, but not abundance. In the SOG, when predator abundances were high, age-0 herring may have spent time and energy reserves avoiding predators rather than feeding. Low growth and condition could have implications for age-0 herring survival because they must store enough energy reserves to survive their first winter, when food is scarce (Paul et al. 1998, Foy \& Paul 1999). Other studies have shown that predator avoidance (including changes in spatial distribution) can negatively affect fish growth and condition (e.g. Casini et al. 2014). Changes in the spatial distribution of fish were not examined in this study and might offer further insights into the dynamics of herring in the SOG.

Sources of uncertainty in this study included the limited number of competitor and predator species examined. We utilized the relative abundance of juvenile salmon as an indicator of predator or competitor abundance. In the SOG, there are other predators, such as adult Chinook O. tshawytscha and coho salmon $O$. kisutch, Pacific hake Merluccius productus, Pacific spiny dogfish Squalus suckleyi, and potentially pinnipeds. There are time series of abundance for indicator salmon stocks (e.g. www.psc.org/ publications/technical-reports/technical-committeereports/chinook/, accessed 28 August 2017); however, they are not necessarily representative of all 
stocks occupying the SOG between July and October or they are not available for several years (e.g. there are limited southern BC coho salmon abundance estimates for 1998 to 2003; see www.psc.org/publications/technical-reports/technical-committee-reports/ coho/, accessed 28 August 2017). Similarly, there are no continuous time series of Pacific hake or Pacific spiny dogfish abundance in the SOG for the years we examined in this study. Also, the proportion of age- 0 herring (as opposed to other age classes) in pinniped diets is not known. These issues can be resolved with modeled predator abundance estimates for years with missing data and with trophodynamic studies that examine both prey species and stage in predator diets. Finally, other factors, such as summer temperatures, summer zooplankton densities, zooplankton community composition and energy densities, and adult herring spawning duration, might improve the amount of deviance explained by the age-0 herring abundance GAM.

Unique to this study was the examination of both age-0 herring abundance and condition. As herring spawning biomass increased, age-0 herring abundance also increased but their condition decreased, indicating the potential for density-dependent growth. Density-dependent processes can affect fish abundance and condition; for example, Dingsør et al. (2007) found that compensatory density-dependent survival was an important process for a few fish species, including Norwegian spring spawning herring. In contrast, Casini et al. (2014) identified the inverse relationship between density and condition for Baltic Sea sprat as spurious, and instead related the reduction in fish condition to predation. Raid et al. (2010) noted that the increased recruitment of Gulf of Riga herring was driven by favourable temperatures that compensated for an observed decrease in herring condition. In the case of the SOG, more spawning adult herring produced more age- 0 fish that may have competed for limited resources during their first months after yolk absorption. Thereby, density dependence may have resulted in reduced body condition during the age- 0 phase due, in part, to intraspecific competition.

Two types of intraspecific competition include competitive (scramble) and interference (contest). We applied a test that was developed for distinguishing between these types of competition (as developed by Ferrer et al. 2006). A linear relationship between the mean and skewness of age-0 herring condition might be indicative of scramble competition because as density increases, individual animals in optimal habitats could maintain a good condition while individu- als that are pushed to suboptimal habitats might have a reduced condition, creating an overall leftskewed distribution of condition (Ferrer et al. 2006, 2008). There was not a linear relationship between skewness and the mean age- 0 herring condition (Fig. 9), indicating that interference competition may be an important process in the SOG. This is consistent with Reum et al.'s (2013) study of Pacific herring in Puget Sound, which found evidence for interference competition.

The predictive value of the SOG age-0 herring abundance time series has been demonstrated by Hay et al. (2003) and Schweigert et al. (2009), who showed that abundance was positively correlated with age-structured stock assessment model estimates of age- 3 recruits (double log transformed and lagged by 3 yr to match the year class), at least through the 2004 year class. Since those 2 analyses, the time series of age- 0 herring and age- 3 recruits (DFO 2018) have been extended (to 2014) and the correlation is significant $\left(\mathrm{R}^{2}=0.80, \mathrm{p}<0.001\right)$. However, 2 years with both low age-0 herring and low age-3 recruit abundances (e.g. 2005 and 2007; Fig. 10) are the primary drivers of this correlation. The age-0 herring survey may therefore provide a leading indicator of low recruitment years. The persistence of the relationship also highlights the importance of continuing this type of monitoring so that future changes in recruitment can be anticipated.

The correlation between age- 0 herring condition and age- 3 recruit abundance was insignificant, with a

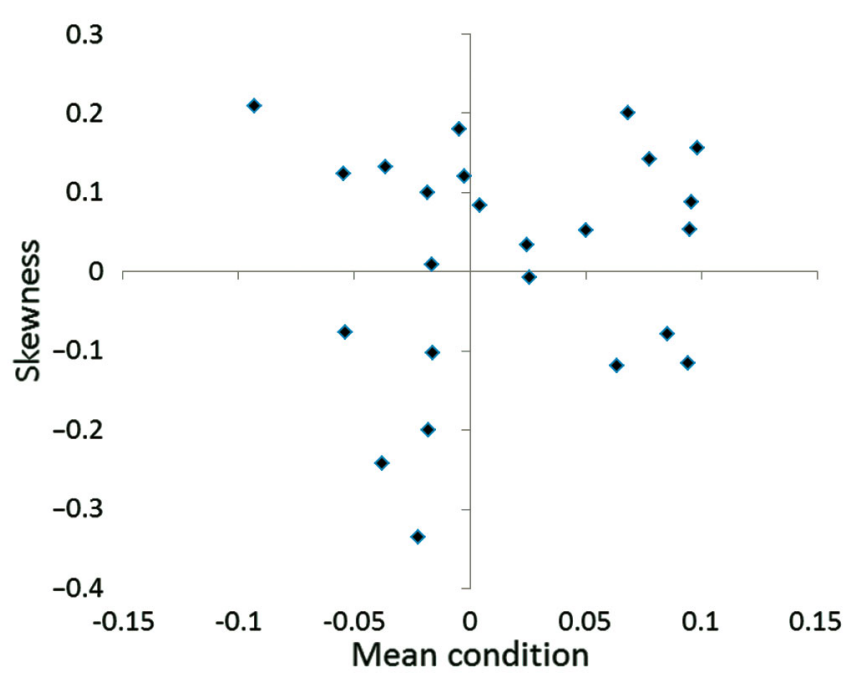

Fig. 9. Skewness as a function of mean condition (i.e. length-weight residuals from a double log-transformed length-weight relationship) of age-0 Pacific herring in the Strait of Georgia, September and October 1992 to 2016 (except 1995) 

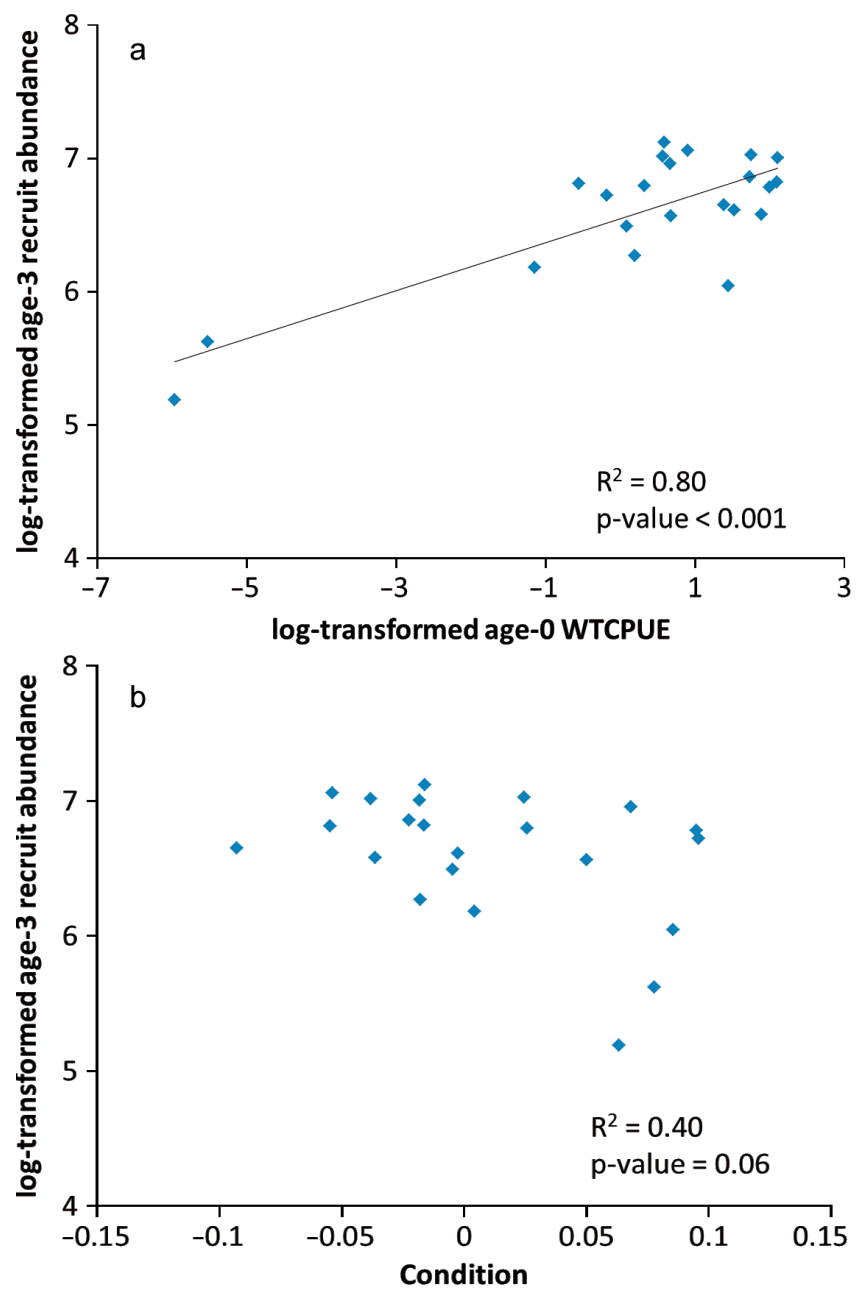

Fig. 10. Age-3 recruit abundance (millions, log transformed, lagged by 3 yr) from an age-structured stock assessment model (a) as a function the age-0 Pacific herring abundance index (log transformed; weight catch per unit effort [CPUE]; $\mathrm{g} \mathrm{m}^{-2}$ ) and (b) as a function of age-0 herring condition (length-weight residuals) in the Strait of Georgia from 1992 to 2016

tendency for lower age-3 recruit abundance to be associated with higher age- 0 condition (lagged by 3 yr; $\mathrm{R}^{2}=0.41, \mathrm{p}=0.06$; Fig. 10). Other studies have found that increased condition could have implications for fecundity and hence reproductive success and recruitment (Raid et al. 2010). Also, fish in good condition have improved survival during their first winter (Paul et al. 1998, Foy \& Paul 1999, Frisk et al. 2015). Perhaps a measure of fish condition in late fall (e.g. November), rather than in September and October, would be more indicative of energy stores age-0 herring have acquired prior to their first winter and might have been more strongly correlated with age-3 recruit abundance. Other factors, such as overall abundance of age-0 herring, may be more important in determining recruitment to the adult population, or factors such as predation may be important during the following 2 yr prior to recruitment to the adult population. Finally, the variance of SOG age-0 herring condition values decreased during the time series, indicating that perhaps more age-0 herring were experiencing favourable feeding conditions in recent years. Further study of the causes and effects of variability in age-0 herring condition are warranted.

In conclusion, this study illustrates that primarily bottom-up processes affect age-0 herring abundance and condition in the SOG, while top-down processes are limited to potential effects on age-0 herring condition. The temporal match between herring and their prey appears to be important, and densitydependent processes, such as interference competition, may affect age-0 herring abundance and condition. The factors affecting herring through their first months of life determine their ability to survive their first winter and eventually recruit to the adult population. Age-0 herring indices of abundance may provide a leading indicator of poor recruitment $2.5 \mathrm{yr}$ in advance. Data from long-term monitoring programs will become increasingly important as climate change influences bottom-up processes that affect herring through spatial and temporal variability in prey and predators.

Acknowledgements. This is Publication Number 14 from the Salish Sea Marine Survival Project (www.marinesurvivalproject.com). Funding was provided by the Pacific Salmon Foundation from 2014 to 2016, by the Herring Conservation and Research Society from 1996 to 2006, and with in-kind contributions by Fisheries and Oceans Canada from 1992 to 2016. Thank you to the skippers of the RV 'Walker Rock' and RV 'Keta': Doug Henderson, Bob Armstrong, and Doug Miller. Thank you to survey participants, Matt Grinnell, Kristen Daniel, Dennis Chalmers, Carol Cooper, Linnea Flostrand, Chuck Parken, Lynda Ritchie, Carl Haegele, Vanessa Hodes, Christa Hrabok, Dan Ware, and Co-op students and volunteers. And thank you to Mary Thiess for survey support, Carol Cooper and Moira Galbraith for zooplankton analysis and data, Susan Allen for providing spring bloom timing data, and Jake Rice for helpful discussions.

\section{LITERATURE CITED}

Alderdice DF, Hourston AS (1985) Factors influencing development and survival of Pacific herring (Clupea harengus pallasi) eggs and larvae to beginning of exogenous feeding. Can J Fish Aquat Sci 42(Suppl 1):56-68

Alderdice DF, Velsen FPJ (1971) Some effects of salinity and temperature on early development of the Pacific herring (Clupea pallasi). J Fish Res Board Can 28:1545-1562

Allen SE, Wolfe MA (2013) Hindcast of the timing of the spring phytoplankton bloom in the Strait of Georgia, 1968-2010. Prog Oceanogr 115:6-13 
Allen S, Latornell D, Olson E, Pawlowicz R (2017) Timing of the spring phytoplankton bloom in the Strait of Georgia, 2016. In: Chandler PC, King SA, Boldt JL (eds) State of the physical, biological and selected fishery resources of Pacific Canadian marine ecosystems in 2016. Can Tech Rep Fish Aquat Sci 3225:171-175

Bailey KM, Houde ED (1989) Predation on eggs and larvae of marine fishes and the recruitment problem. Adv Mar Biol 25:1-83

Bakun A (1993) The California Current, Benguela Current, and South-western Atlantic Shelf ecosystems: a comparative approach to identifying factors regulating biomass yields. In: Sherman K, Alexander LM, Gold B (eds) Large marine ecosystems: stress, mitigation, and sustainability American Association for the Advancement of Science, Washington, DC, p 199-224

Beamish RJ, Sweeting RM, Neville CM (2004) Improvement of juvenile Pacific salmon production in a regional ecosystem after the 1998 climatic regime shift. Trans Am Fish Soc 133:1163-1175

Beamish RJ, Neville C, Sweeting R, Lange K (2012) The synchronous failure of juvenile Pacific salmon and herring production in the Strait of Georgia in 2007 and the poor return of sockeye salmon to the Fraser River in 2009. Mar Coast Fish 4:403-414

Boldt JL, Thompson M, Fort C, Rooper CN and others (2015) An index of relative biomass, abundance, and condition of juvenile Pacific herring (Clupea pallasi) in the Strait of Georgia, British Columbia. Can Manuscr Rep Fish Aquat Sci 3081:1-80

Brunel T, Dickey-Collas M (2010) Effects of temperature and population density on von Bertalanffy growth parameters in Atlantic herring: a macro-ecological analysis. Mar Ecol Prog Ser 405:15-28

Buchheister A, Wilson MT (2005) Shrinkage correction and length conversion equations for Theragra chalcogramma, Mallotus villosus and Thaleichthys pacificus. J Fish Biol 67:541-548

Casini M, Cardinale M, Hjelm J (2006) Inter-annual variation in herring, Clupea harengus, and sprat, Sprattus sprattus, condition in the central Baltic Sea: What gives the tune? Oikos 112:638-650

Casini M, Rouyer T, Bartolino V, Larson N, Grygiel W (2014) Density-dependence in space and time: opposite synchronous variations in population distribution and body condition in the Baltic Sea Sprat (Sprattus sprattus) over three decades. PLOS ONE 9:e92278

Cury P, Bakun A, Crawford RJM, Jarre A, Quinones RA, Shannon LJ, Verheye HM (2000) Small pelagics in upwelling systems: patterns of interaction and structural changes in 'wasp-waist' ecosystems. ICES J Mar Sci 57: 603-618

Cushing DH (1969) The regularity of the spawning season of some fishes. ICES J Mar Sci 33:81-92

Cushing DH (1972) The production cycle and the numbers of marine fish. Symp Zool Soc Lond 29:213-232

Cushing DH, Harris JGK (1973) Stock and recruitment and the problem of density dependence. Rapp P-V Reùn Cons Int Explor Mer 164:142-155

DFO (Department of Fisheries and Oceans Canada) (2018) Stock assessment for Pacific herring (Clupea pallasi) in British Columbia in 2017 and forecast for 2018. DFO Can Sci Advis Sec Sci Advis Rep 2018/002

Dingsør GE, Ciannelli L, Chan KS, Ottersen G, Senseth NC (2007) Density dependence and density independence during the early life stages of four marine fish stocks. Ecology 88:625-634

* Dreyfus-León M, Chen DG (2007) Recruitment prediction with genetic algorithms with application to the Pacific herring fishery. Ecol Modell 203:141-146

* Dreyfus-León M, Schweigert J (2008) Recruitment prediction for Pacific herring (Clupea pallasi) on the west coast of Vancouver Island, Canada. Ecol Inform 3:202-206

* Duffy EJ, Beauchamp DA, Sweeting RM, Beamish RJ, Brennan JS (2010) Ontogenetic diet shifts of juvenile Chinook salmon in nearshore and offshore habitats of Puget Sound. Trans Am Fish Soc 139:803-823

* Emmett RL, Brodeur RD, Orton PM (2004) The vertical distribution of juvenile salmon (Oncorhynchus spp.) and associated fishes in the Columbia River plume. Fish Oceanogr 13:392-402

Ferrer M, Newton I, Casado E (2006) How to test different density-dependent fecundity hypotheses in an increasing or stable population. J Anim Ecol 75:111-117

*Ferrer M, Newton I, Casado E (2008) Density dependence hypotheses and the distribution of fecundity. J Anim Ecol 77:341-345

Flinkman J, Aro E, Vuorinen I, Viitasalo M (1998) Changes in northern Baltic zooplankton and herring nutrition from 1980s to 1990s: top-down and bottom-up processes at work. Mar Ecol Prog Ser 165:127-136

Foy RJ, Paul AJ (1999) Winter feeding and changes in somatic energy content of age-0 Pacific herring in Prince William Sound, Alaska. Trans Am Fish Soc 128:1193-1200

Frisk C, Andersen KH, Temming A, Herrmann JP, Madsen KS, Kraus F (2015) Environmental effects on sprat (Sprattus sprattus) physiology and growth at the distribution frontier: a bioenergetic modelling approach. Ecol Modell 299:130-139

Froese R (2006) Cube law, condition factor and weightlength relationships: history, meta-analysis and recommendations. J Appl Ichthyol 22:241-253

Haegele CW (1997) The occurrence, abundance and food of juvenile herring and salmon in the Strait of Georgia, British Columbia in 1990 to 1994. Can Manuscr Rep Fish Aquat Sci 2390:1- 124

Haegele CW, Armstrong RW (1997) Juvenile herring survey of the Strait of Georgia, June and September 1996. Final report submitted to the Herring Conservation and Research Society. Armstrong Bio/Tech Services, Nanaimo

* Haegele CW, Humphreys RD, Hourston AS (1981) Distribution of eggs by depth and vegetation type in Pacific herring (Clupea harengus pallasi) spawnings in southern British Columbia. Can J Fish Aquat Sci 38:381-386

Haegele CW, Hay DE, Schweigert JF, Annstrong RW, Hrabok C, Thompson M, Daniel K (2005) Juvenile herring surveys in Johnstone and Georgia Straits: 1996 to 2003. Can Data Rep Fish Aquat Sci 1171:1-243

*Hay DE (1985) Reproductive biology of Pacific herring (Clupea harengus pallasi). Can J Fish Aquat Sci 42(Suppl 1): $111-126$

Hay DE, Schweigert JF, Thompson M, Haegele CW, Midgley P (2003) Analyses of juvenile surveys for recruitment prediction in the Strait of Georgia. Can Sci Advis Sec Res Doc 2003/107. Department of Fisheries and Oceans Canada, Nanaimo

Hjort J (1914) Fluctuation in the great fisheries of northern Europe reviewed in the light of biological research. Rapp P-V Reùn Cons Int Explor Mer 20:1-228 
Houde E (1987) Fish early life dynamics and recruitment variability. Am Fish Soc Symp 2:17-29

Humphreys RD, Hourston AS (1978) British Columbia herring spawn deposition survey manual. Miscellaneous Special Publication 38, Department of Fisheries and Marine Service, Ottawa

Kemp IM (2014) Spatial-temporal patterns in distribution and feeding of juvenile salmon and herring in Puget Sound, WA. MSc thesis, University of Washington, Seattle, WA

Lasker R (1975) Field criteria for survival of anchovy larvae: the relation between inshore chlorophyll maximum layers and successful first feeding. Fish Bull 73: 453-462

Leggett WC, Deblois E (1994) Recruitment in marine fishes: Is it regulated by starvation and predation in the egg and larval stages? Neth J Sea Res 32:119-134

Mackas D, Galbraith M, Faust D, Masson D and others (2013) Zooplankton time series from the Strait of Georgia: results from year-round sampling at deep water locations, 1990-2010. Prog Oceanogr 115:129-159

* Meekan MG, Fortier L (1996) Selection for fast growth during the larval life of Atlantic cod Gadus morhua on the Scotian Shelf. Mar Ecol Prog Ser 137:25-37

Outram DN (1955) The development of the Pacific herring egg and its use in estimating age of spawn. Pacific Biological Station Circular No. 40, Fisheries Research Board of Canada, Nanaimo

Parrish RH, Nelson CS, Bakun A (1981) Transport mechanisms and reproductive success of fishes in the California Current. Biol Oceanogr 1:175-203

*Paul AJ, Paul JM, Brown ED (1998) Fall and spring somatic energy content for Alaskan Pacific herring (Clupea pallasi Valenciennes 1847) relative to age, size and sex. J Exp Mar Biol Ecol 223:133-142

Perry RI, Schweigert JF (2008) Primary productivity and the carrying capacity for herring in the NE Pacific marine ecosystems. Prog Oceanogr 77:241-251

Preikshot D, Beamish RJ, Neville CM (2013) Dynamic model describing ecosystem-level changes in the Strait of Georgia from 1960 to 2010. Prog Oceanogr 115:28-40

R Core Team (2014) R: a language and environment for statistical computing. R Foundation for Statistical Computing, Vienna

Raid T, Kornilovs G, Lankov A, Nisumaa AM, Shiplev H, Jarvik A (2010) Recruitment dynamics of the Gulf of Riga herring stock: density-dependent and environmental effects. ICES J Mar Sci 67:1914-1920

Reum JC, Essington TE, Greene CM, Rice CA, Polte P, Fresh KL (2013) Biotic and abiotic controls on body size during critical life history stages of a pelagic fish, Pacific herring (Clupea pallasii). Fish Oceanogr 22:324-336

Scholz F, Zhu A (2016) kSamples: k-sample rank tests and their combinations. $\mathrm{R}$ package version 1.2-3. http:// CRAN.R-project.org/package=kSamples (accessed 28 Aug 2017)

Schweigert JF (1993) A review and evaluation of methodology for estimating Pacific herring egg deposition. Bull Mar Sci 53:818-841

Schweigert JF, Noakes DJ (1990) Forecasting Pacific herring (Clupea harengus pallasi) recruitment from spawner abundance and environmental information. In: Proc Int Herring Symposium, 23-25 Oct 1990, Anchorage, Alaska. Alaska Sea Grant Report No. 91-01, Fairbanks, AK, p 373-387
Schweigert JF, Hay DE, Therriault TW, Thompson M, Haegele CW (2009) Recruitment forecasting using indices of young-of-the year Pacific herring (Clupea pallasi) abundance in the Strait of Georgia (BC). ICES J Mar Sci 66:1681-1687

Schweigert JF, Boldt JL, Flostrand L, Cleary JS (2010) A review of factors limiting recovery of Pacific herring stocks in Canada. ICES J Mar Sci 67:1903-1913

* Schweigert JF, Thompson M, Fort C, Hay DE, Therriault TW, Brown LN (2013) Factors linking Pacific herring (Clupea pallasi) productivity and the spring plankton bloom in the Strait of Georgia, British Columbia, Canada. Prog Oceanogr 115:103-110

Sinclair M, Iles TD (1989) Population regulation and speciation in the oceans. ICES J Mar Sci 45:165-175

Smith RL, Paul AJ, Paul JM (1986) Effect of food intake and temperature on growth and conversion efficiency of juvenile walleye pollock (Theragra chalcogramma (Pallas)): a laboratory study. ICES J Mar Sci 42:241-253

* Stocker M, Noakes DJ (1988) Evaluating forecasting procedures for predicting Pacific herring (Clupea harengus pallasi) recruitment in British Columbia. Can J Fish Aquat Sci 45:928-935

* Stocker M, Haist V, Fournier D (1985) Environmental variation and recruitment of Pacific herring (Clupea harengus pallasi) in the Strait of Georgia. Can J Fish Aquat Sci 42(Suppl 1):174-180

Szarzi NJ, Quinn TJ II, McBride DN (1995) Assessment of shallow-water clam resources: case study of razor clams, eastern Cook Inlet, Alaska. ICES Mar Sci Symp 199: 274-286

Taylor FCH (1964) Life history and present status of British Columbia herring stocks. Bulletin of the Fisheries Research Board of Canada, 143, Ottawa

Taylor FCH (1971) Variation in hatching success in Pacific herring (Clupea pallasii) eggs with water depth, temperature, salinity and egg mass thickness. Rapp P-V Reùn Cons Int Explor Mer 100:34-41

Thompson SK (1992) Sampling. John Wiley \& Sons, New York, NY

Thompson M, Boldt JL (in press) Strait of Georgia juvenile herring survey, September 2015. Can Manuscr Rep Fish Aquat Sci

Thompson M, Hrabok C, Hay DE, Schweigert J, Haegele C, Armstrong B (2003) Juvenile herring surveys: methods and data base. Can Manuscr Rep Fish Aquat Sci 2651:1-31

Thompson M, Fort C, Schweigert J (2013) Strait of Georgia juvenile herring survey, September 2011 and 2012. Can Manuscr Rep Fish Aquat Sci 3016:1-63

Thompson M, Boldt JL, Grinnell MH (in press) Strait of Georgia juvenile herring survey, September 2016. Can Manuscr Rep Fish Aquat Sci

* Toresen R, Ostvedt OJ (2000) Variation in abundance of Norwegian spring-spawning herring (Clupea harengus, Clupeidae) throughout the 20th century and the influence of climatic fluctuations. Fish Fish 1:231-256

Tucker S, Hipfner M, Trudel M (2016) Size- and conditiondependent predation: a seabird disproportionately targets substandard individual juvenile salmon. Ecology 97 : 461-471

*Ware DM, Thomson RE (2005) Bottom-up ecosystem trophic dynamics determine fish production in the northeast Pacific. Science 308:1280-1284

*Weinberg KL, Kotwicki S (2008) Factors influencing net width and sea floor contact of a survey bottom trawl. Fish 
Res 93:265-279

Williams EH, Quinn TJ II (2000) Pacific herring, Clupea pallasi, recruitment in the Bering Sea and north-east Pacific Ocean. II: Relationships to environmental variables and implications for forecasting. Fish Oceanogr 9: 300-315

Winters GH, Wheeler JP, Dalley EL (1986) Survival of a herring stock subjected to a catastrophic event and fluctuating environmental conditions. ICES J Mar Sci 43:26-42

Wood SN (2004) Stable and efficient multiple smoothing parameter estimation for generalized additive models. J Am Stat Assoc 99:673-686

Wood SN (2006) Generalized additive models: an introduc-

Editorial responsibility: Dominique Robert (Guest Editor), Rimouski, Quebec, Canada tion with R. CRC Press, Boca Raton, FL

*Wood SN, Augustin NH (2002) GAMs with integrated model selection using penalized regression splines and applications to environmental modelling. Ecol Modell 157: $157-177$

Zebdi A, Collie JS (1995) Effect of climate on herring (Clupea pallasi) population dynamics in the Northeast Pacific Ocean. In: Beamish RJ (ed) Climate change and northern fish populations. Can Spec Publ Fish Aquat Sci 121: $277-290$

Zuur AF, Ieno EN, Walker NJ, Saveliev AA, Smith GM (2009) Mixed effects models and extensions in ecology with R. Springer, New York, NY

Submitted: September 1, 2017; Accepted: January 14, 2018 Proofs received from author(s): March 5, 2018 